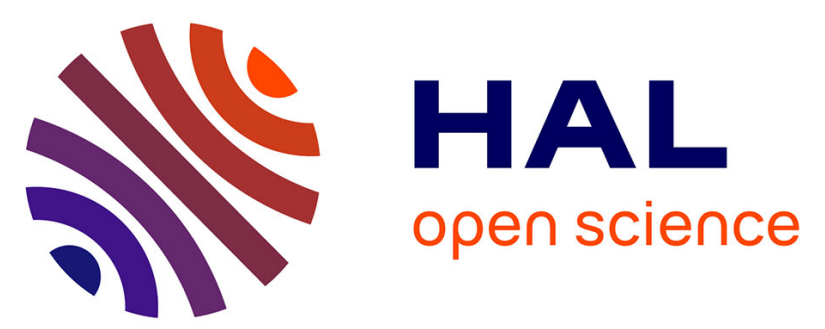

\title{
Assessing the potential of routine stand variables from multi-taxon data as habitat surrogates in European temperate forests
}

Laurent L. Larrieu, Frédéric Gosselin, Frédéric Archaux, Richard Chevalier, G. Corriol, E. Dauffy Richard, Marc Deconchat, Marion Gosselin, Sylvie Ladet, J.M. Savoie, et al.

\section{To cite this version:}

Laurent L. Larrieu, Frédéric Gosselin, Frédéric Archaux, Richard Chevalier, G. Corriol, et al.. Assessing the potential of routine stand variables from multi-taxon data as habitat surrogates in European temperate forests. Ecological Indicators, 2019, 104, pp.116-126. 10.1016/j.ecolind.2019.04.085 . hal02609972

\section{HAL Id: hal-02609972 \\ https://hal.inrae.fr/hal-02609972}

Submitted on 22 Oct 2021

HAL is a multi-disciplinary open access archive for the deposit and dissemination of scientific research documents, whether they are published or not. The documents may come from teaching and research institutions in France or abroad, or from public or private research centers.
L'archive ouverte pluridisciplinaire HAL, est destinée au dépôt et à la diffusion de documents scientifiques de niveau recherche, publiés ou non, émanant des établissements d'enseignement et de recherche français ou étrangers, des laboratoires publics ou privés.

\section{다)(1) $(5$}

Distributed under a Creative Commons Attribution - NonCommerciall 4.0 International 


\section{Assessing the potential of routine stand variables from multi-taxon data as habitat surrogates in}

\section{European temperate forests}

3 Laurent LARRIEU *ab, Frédéric GOSSELIN ${ }^{c}$, Frédéric ARCHAUX ${ }^{c}$, Richard CHEVALIER ${ }^{c}$, Gilles CORRIOL

$4{ }^{d}$, Emmanuelle DAUFFY-RICHARD ${ }^{c \text { th }}$, Marc DECONCHAT ${ }^{\text {a }}$, Marion GOSSELIN ${ }^{c}$, Sylvie LADET ${ }^{\text {a }}$, Jean-

5 Marie SAVOIE ${ }^{\text {a }}$, Laurent TILLON ${ }^{\mathrm{e}}$, Christophe BOUGET ${ }^{\mathrm{c}}$

$6{ }^{*}$ corresponding author

7 a UMR 1201 DYNAFOR, INRA, INPT, INPT-EI Purpan, Université de Toulouse, 31320 Auzeville

8 Tolosane, France, laurent.larrieu@inra.fr, marc.deconchat@inra.fr, sylvie.ladet@inra.fr,

$9 \quad j m . s a v o i e @ p u r p a n . f r$

${ }^{b}$ CRPF-Occitanie, antenne de Tarbes, place du foirail, 65000 Tarbes, France, laurent.larrieu@crpf.fr

' Irstea, UR EFNO, Domaine des Barres, 45290 Nogent-sur-Vernisson, France, frederic.archaux@irstea.fr, richard.chevalier@irstea.fr, frederic.gosselin@irstea.fr, marion.gosselin@irstea.fr, christophe.bouget@irstea.fr

d CBNPMP, vallon du Salut, 65203 Bagnères de Bigorre Cedex, France, gilles.corriol@cbnpmp.fr

e ONF DFRN, 2, avenue de Saint-Mandé 75570 Paris cedex 12, France, laurent.tillon@onf.fr

"Deceased

Abstract

To encourage forest managers to use biodiversity indicators in their work, providing environmental variables that depict species habitats, have well-calibrated and strong relationships with biodiversity and are easy to routinely record would be a step forward. The Index of Biodiversity Potential (IBP) is a rapid habitat assessment method widely used in France. It uses ten variables that indicate potential habitat for forest-dwelling species and is easy for forest managers to implement during their day-today activities. The objective of this paper is to evaluate the indicator power of these IBP variables at the stand scale, i.e. their capacity to co-vary with empirical species richness and composition data for nine taxa. The data were obtained from 487 plots set up in 19 forested areas in France. Taxonomic data focused on corticolous lichens, corticolous and saproxylic bryophytes, polypores, saproxylic beetles, ground beetles, hoverflies, birds, bats and vascular plants. For the latter five taxa, we built subgroups of forest-specialist species. The IBP variables were recorded on 1-ha circular plots centered on the sampling point used to record taxonomic data. We explored the relationships between the IBP variables and species composition/richness of nine taxa at the stand scale. Furthermore, we searched for threshold values for all the significant relationships found between species richness and the IBP variables. Variations in the species composition of vascular plants and saproxylic beetles, and to a lesser extent, polypores, bats and lichens, were significantly related to habitat variations (ranked according to the Procrustes significance level). The contribution of the IBP variables to the total inertia of species composition was about $18.7 \%$ on average. The IBP variables 
had a lower number of significant relationships with species richness than with species composition. Unexpectedly, the forest subgroups mainly showed fewer significant relationships with habitat variables than did the full-groups, both for species richness and composition. We highlighted seven 40 significant thresholds in the habitat variables above which species richness was significantly higher.

41 Finally, we recommend that forest managers (i) routinely use a rapid habitat assessment such as the IBP, (ii) orient silvicultural practices to ensure conservation of autochtonous tree species, large logs and different types of aquatic habitats above the thresholds highlighted in this study, and (iii) periodically complete a biodiversity assessment at the forest scale by recording taxonomic data.

Key words: IBP; covariation; biodiversity; stand structure; species richness; species composition

Highlights

- Composition of plants and saproxylic beetles assemblages co-varied with habitat variables

- The contribution of habitat variables to species composition inertia was relatively weak

- Forest subgroups showed weaker relationships with habitat variables than did full-taxa

- We found seven habitat thresholds above which species richness was significantly higher 


\section{Introduction}

Forests are crucial habitats for biodiversity since they support about two-thirds of the world's terrestrial biodiversity (WCFSD, 1999). In Europe, most forests have been managed for a long time (Larsson et al. 2001), and this has had a major impact on their biodiversity (e.g. Mitchell and Kirby 1989). The concept of sustainable forest management, which emerged at the 1992 Rio conference on Environmental Development, requires forest managers to maintain species diversity in managed areas (FAO 2015). However, taxonomic inventories are time-consuming and involve specialists, and therefore cannot be easily implemented by forest managers in their daily routine. Having said this, some quick, easy methods ("rapid habitat assessments") exist to survey key structural elements and succinctly describe the habitats typical of various forest taxa (Venier and Mackey 1997). Lindenmayer et al. (2000) suggested using environmental variables as biodiversity indicators. Testing and validating easy-to-record stand variables that depict species habitats and are relevant as biodiversity indicators would encourage forest managers to integrate these indicators into their typical working activities. . Larsson et al. (2001) proposed a list of key compositional, structural and functional environmental factors for each main European forest type. In the same way, Lindenmayer et al. (2006) suggested using keystone elements to improve and monitor eco-friendly forest management. Their focus was mainly on deadwood and tree-related microhabitats (TreMs) (Tews et al. 2004; Kraus and Krumm 2013). Composite indices, based on large-scale field data available from state forest inventories, have already been used in habitat assessment protocols (e.g. The Stand-scale Forest Biodiversity Index, Van Den Meersschaut and Vandekerkhove, 1998; the Austrian Forest Biodiversity Index, Geburek et al. 2010; The Biotope Value of the Forest Stand, WSL 2001). At the local (i.e. stand) scale, other indicator lists exist (e.g. Indicators of High Conservation Value Forest, Jennings et al. 2003; the European forest scorecards, Sollander 2000; The Rapid Appraisal of Riparian Condition, Jansen et al. 2004).

Unfortunately, the studies to date have not identified habitat indicators that are fully relevant for all taxa and all forest contexts (e.g. Bouget et al. 2014a; Van Den Meersschaut and Vandekerkhove 1998), and significant relationships between structural indicators and taxa has clearly been shown in only a very limited number of cases (Gao et al. 2015). Furthermore, most previous studies have focused on species richness, while the relationships between indicators and species composition have been poorly studied (Gao et al. 2015). Finally, Gao et al. (2015) recommended that environmental variables be further validated for forest ecosystems. 
We chose to focus on species subgroups such as forest specialists (Gosselin 2012), since they are often the main targets of forest conservation, and to emphasize the stand scale, since it is the main operational scale for forest managers (Failing and Gregory 2003). The habitat variables the most commonly tested at the stand scale in previous studies have been tree age, tree canopy cover, deadwood volume and deadwood diversity (Gao et al. 2015). Few studies have tested other variables such as shrub cover, vertical stratification, stand basal area, tree height, volume of standing trees, TreMs or tree species composition (Gao et al. 2014; Gao et al. 2015). However, most of these variables require not only field measurements but also subsequent calculations. The objective of our study was to evaluate habitat variables that are easy to record in the field without specialized devices and that do not require post-calculations for their indicator power at the stand scale. We therefore used the ten variables already selected for a rapid habitat assessment method designed for routine use in the field: the Index of Biodiversity Potential (IBP; Larrieu and Gonin 2008). The IBP index is already being used in France by many forest managers. It combines ten factors deemed to favor biodiversity, most of which focus on precise items either already typically observed by managers for economic issues, or easy to observe in the field without any tools or devices. We investigated the relationships between empirical species richness and composition data for nine taxa according to these ten variables.

\section{Material and methods}

Taxonomic data were recorded following standardized procedures at the stand level, within the framework of several different research projects (Table A1 in Supplementary Material). We used data from 487 plots situated in 19 French forested areas (Fig 1). The wide range of forest contexts sampled represented both the Atlantic and Continental zones, forests from lowlands to highlands, and broadleaved, conifer-dominated and mixed stands (Fig. 1 and Table A2 in Supp. Mat.)

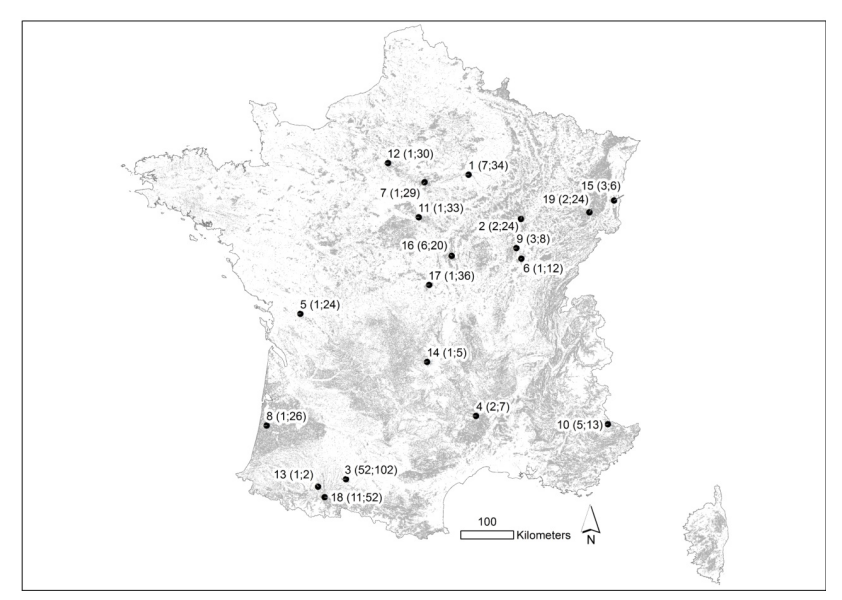


Fig. 1. Map of the 19 forested areas sampled; in brackets for each area, the number of forests sampled followed by the number of sampling plots; 1:Aube, 2:Auberive, 3:Coteaux de Gascogne, 4:Cévennes, 5:Chizé, 6:Citeaux, 7:Fontainebleau, 8:Landes de Gascogne, 9:Lavaux, 10:Mercantour, 11:Orléans, 12:Rambouillet, 13:Rebisclou, 14:Rhue, 15:Taillis.A, 16:Taillis.B, 17:Tronçais, 18:Vieilles Forêts des Pyrénées, 19:Vosges

\subsection{Rapid forest habitat assessment}

All the stands were characterized by the same observer on a 1-ha circular plot centered on the sampling point where taxonomic data were recorded. The observers followed the protocol for the Index of Biodiversity Potential (IBP; Larrieu and Gonin, 2008), which includes attentive observation while crisscrossing the stand. Nine of the ten IBP factors belong to three broad categories: (i) living vegetation: number of native tree-species and number of vertical strata; (ii) deadwood and TreMs: number of large snags, large lying deadwood items, very large trees and living TreM-bearing trees; (iii) associated features: open areas, number of aquatic macrohabitat types and rocky macrohabitat types. In addition, we replaced the broad IBP variable "Number of TreM-bearing trees" by its seven constituting variables (Table 1); these variables were used only for relationships between habitat variables and species richness. In all then, a total of 16 compositional and structural stand characteristics (Table 1) were simultaneously recorded on site. Ancientness is also taken into account by the IBP protocol as an additional factor since recent and ancient forests show significant differences in biodiversity (Assman 1999; Gossner et al. 2008; Hermy et al. 1999; Diedhiou et al. 2009). In France, a military survey map showing land use over a large part of the territory (called "Etat Major") was published in the mid-19 $19^{\text {th }}$ century.; Current forests already indicated on this map are considered likely to have never been cleared or replaced with another land use (Dupouey et al. 2002). Ancientness was post-recorded at the office.

Finally, we recorded four other covariables: biogeographic domain, location of forested area, altitude and dominant tree-species (Table 1). Hereafter, the term "habitat variables" refers to the IBP constituting variables, while "environmental variables" refers to the total pool of both IBP constituting variables and the four covariables mentioned above.

Since the aim of this study was to assess the potential of routine variables as robust habitat surrogates for certain taxa, and not to assess the relevance of the IBP index per se, we did not test the IBP scoring system. 
Table 1. Stand-characterizing habitat variables and covariables; values are at the 1ha-plot scale; $d=$ diameter, L=length; SE=standard error; in italics: variable 146 derived from a map or computed

\begin{tabular}{|c|c|c|c|c|c|c|c|}
\hline $\begin{array}{l}\text { Broad } \\
\text { categories }\end{array}$ & Type of variable & $\begin{array}{l}\text { IBP's factor } \\
\text { number }\end{array}$ & $\begin{array}{l}\text { Variable } \\
\text { (Variable number) }\end{array}$ & Definition & Median & Mean (SD) & $\begin{array}{l}\text { Value } \\
\text { range } \\
\text { (min- } \\
\text { max) }\end{array}$ \\
\hline \multirow[t]{5}{*}{ Covariables } & Covariables & & site & Forested area & & & \\
\hline & & & domain & $\begin{array}{l}\text { Biogeographic domain: Atlantic or } \\
\text { Continental }\end{array}$ & & & \\
\hline & & & alt & $\begin{array}{l}\text { Bioclimatic level: lowlands (plain and } \\
\text { hilly levels) or highlands (montane } \\
\text { and lower-subalpine levels) }\end{array}$ & & & \\
\hline & & & broadconif & Tree-species dominance: & & & \\
\hline & & & & $\begin{array}{l}\text { Broadleaved- (broad), conifer- (conif) } \\
\text { dominated or mixed (mixed) stands }\end{array}$ & & & \\
\hline \multirow[t]{3}{*}{ Vegetation } & Diversity of tree-species & 1 & nb.ts (1) & Number of autochthonous tree- & 5 & $5.17(2.26)$ & $0-12$ \\
\hline & & & & species (dead and living trees) & & & \\
\hline & Vertical structure of vegetation & 2 & nb.strata (2) & $\begin{array}{l}\text { Number of vertical strata with cover } \\
>10 \% \text { (max=4 ; field cover layer, } 0.5- \\
7 m, 7-20 m,>20 m)\end{array}$ & 4 & $3.70(0.52)$ & $2-4$ \\
\hline \multirow{4}{*}{$\begin{array}{l}\text { Deadwood } \\
\text { and Tree- } \\
\text { related } \\
\text { microhabitats } \\
\text { (TReMs) }\end{array}$} & Deadwood & 3 & nb.snags (3) & $\begin{array}{l}\text { Number of large snags }(\mathrm{d}>37,5 \mathrm{~cm} \\
\text { and } L \geq 1 \mathrm{~m})\end{array}$ & 1 & $2.69(4.65)$ & $0-31$ \\
\hline & & 4 & nb.logs (4) & $\begin{array}{l}\text { Number of large lying deadwood } \\
\text { items }(d>37,5 \mathrm{~cm} \text { et } L \geq 1 \mathrm{~m})\end{array}$ & 1 & $4.67(8.41)$ & $0-57$ \\
\hline & Very large trees & 5 & nb.vlt (5) & $\begin{array}{l}\text { Number of very large trees } \\
(d>67,5 \mathrm{~cm})\end{array}$ & 2 & $6.54(9.37)$ & $0-58$ \\
\hline & TReM-bearing trees & & nb.cav (6) & $\begin{array}{l}\text { Number of living cavity-bearing } \\
\text { trees: woodpecker breeding and }\end{array}$ & 4 & $6.80(12.31)$ & $0-161$ \\
\hline
\end{tabular}


feeding holes, root buttress

concavities, with an entrance above

$3 \mathrm{~cm}$ in width; rot-holes with an

entrance above $10 \mathrm{~cm}$ in width

nb.crack (7)

nb.sap (8)

nb.unbark (9)

nb.fun (10)

nb.pdw (11)

nb.epiph (12)

Number of trees with living cracks (or 0

eling bark forming a shelter)

Number of trees with sap-runs $>10$

$\mathrm{cm}$ in length

Number of living trees with missing-

bark (surface $>600 \mathrm{~cm}^{2}$ ); sapwood is

slightly altered

Number of fungus-bearing trees: at

least one fruiting body of a polypore

Number of trees with crown

deadwood (large dead branches $>20$

$\mathrm{cm}$ in diameter and $>1 \mathrm{~m}$ in length

crown deadwood volume $>20 \%$ of

the total crown wood volume

Number of living epiphyte-bearing

trees: more than $30 \%$ of the trunk

surface is covered by ivy or liana

Number of living trees bearing at

$2.36(3.64)$

east one tree-related microhabitat.

Trees with more than one

microhabitat of the same type were

counted only once, but trees bearing

more than one microhabitat type

were counted once for each

microhabitat type

div.trem

Number of tree-related microhabitat

types observed (among a list of 7 types)

open (14)

0

$0.64(1.27)$

$4.57(6.19)$

Open areas (clearings, edges and

3

areas with very little canopy cover)

with a well-developed field layer 
composed of flowering plants (\%)

\begin{tabular}{|c|c|c|c|c|c|c|}
\hline \multirow[t]{2}{*}{ Associated macrohabitats } & 8 & nb.aqua (15) & $\begin{array}{l}\text { Number of aquatic macrohabitat } \\
\text { types (among spring, stream, } \\
\text { backwater, pond, lake, bog, non- } \\
\text { forested marshes) }\end{array}$ & 0 & $0.35(0.67)$ & $0-4$ \\
\hline & 9 & nb.rock (16) & $\begin{array}{l}\text { Number of rocky macrohabitat types } \\
\text { (among cliff, stable or unstable scree, } \\
\text { large boulders, slab and other rock } \\
\text { outcrops, cave ) }\end{array}$ & 0 & $0.41(0.84)$ & $0-4$ \\
\hline Ancientness & 10 & ancient (17) & $\begin{array}{l}\text { The forest is present on the historic } \\
\text { "Etat Major" map (19th century) }\end{array}$ & - & - & - \\
\hline
\end{tabular}




\subsection{Taxonomic data}

149 Our study targets nine taxa that are widespread in forest ecosystems covering, a priori, a wide range 150 of habitat requirements. Four taxa were intrinsically associated with forests, trees, woody substrates or forest-buffered climatic conditions: corticolous lichens, corticolous or saproxylic bryophytes, polypores and saproxylic beetles. Five other taxa- namely ground beetles, hoverflies, birds, bats and vascular plants - had a more heterogeneous ecology. Based on Coulon et al. (2000), Speight et al. (2015), Cramp et al. (1980-94) Arthur and Lemaire (2009) and Rameau et al. (1989, 1999), respectively, we singled out forest specialist subgroups in the assemblages of these five taxa. We defined the subgroups as follows: (i) the forest ground beetle subgroup includes species that are mainly observed in forest ecosystems; (ii) the forest bird subgroup includes species that are mainly observed in forest ecosystems, including tree cavity-dwellers; (iii) the forest bat subgroup includes species using cavities or peeling-barks for resting or breeding; (iv) the forest vascular plant subgroup includes species that are able to grow under closed canopy. Ultimately, we gathered data on one to seven taxa per plot (Table A3) for a total of 14 taxonomic variables (i.e. 9 full groups plus 5 subgroups). (Table A4). Sampling procedures are specified in Table A1.

\subsection{Data analyses}

All the analyses were performed at the plot level. Since several taxa were recorded for presence/absence only (e.g. polypore, bats, bryophytes, lichens), we did not use abundance values in the analyses.

\subsubsection{Compositional analysis}

First, we explored the congruence between the between-plot dissimilarity matrix based on pooled habitat variables (see the set of metrics in Table 1) and the between-plot dissimilarity matrix based on species composition (for each of the nine taxa). To do so, we performed a Procrustes rotation on non-metric multi-dimensional scaling (NMDS) ordinations (Peres-Neto and Jackson 2001) of the BrayCurtis dissimilarity matrix for habitat variables and the Jaccard dissimilarity matrix for species occurrence data. Permutation tests associated to the Procrustes method (protest function, R-package Vegan, with the $\mathrm{m}^{2}$ Procrustes statistic; number of runs=1,000) revealed the non-randomness of the congruence in fit between multivariate data tables. In order to account for the nested structure of our dataset, permutations were conditioned upon forested area, which was a stratifying variable.

178 Next, we performed a Canonical Analysis of Principal Coordinates (CAP, Anderson and Willis 2003;

179 capscale function, R-package Vegan) to investigate the effects of each habitat feature on variations in 
species composition for each taxonomic assemblage. Inertia was partitioned from Jaccard's distance matrices (vegdist function, R-package Vegan) on all explanatory habitat variables, since co-linearity among predictor variables is not a problem in CAP (Anderson and Willis 2003). After partialling out the geographical effect (i.e. forested area), both in the full CAP combining all the habitat variables and in the individual CAPs performed for each habitat variable, we calculated the proportion of inertia cumulatively explained by all the habitat variables, the relative total contribution (intrinsic + co-explained) of each habitat variable to the total inertia and the statistical significance of this contribution (by means of permutation tests - 999 runs).

\subsubsection{Species richness analysis}

We used multi-model averaged estimates (Burnham and Anderson 2002) to determine the relationship between each of the 14 taxonomic variables for species richness and each of the environmental variables. For each response variable (count data), we generated Poisson Generalized Linear Mixed Models (GLMM, g/mer function, R-package Ime4). The mixed models enabled us to include forested area as a random variable. Since co-linearity among predictor variables may lead to unreliable parameter estimates, we followed the strategy suggested by Zuur et al. (2010) to address the multicolinearity problem before model averaging. First, we sequentially dropped the covariate with the highest variance inflation factor (VIF; vif.mer function from Frank 2011), then recalculated the VIF; we repeated this process until all VIFs were below the cutoff value of 3 suggested by Zuur et al. (2010). Then, we generated models with all the combinations of the remaining variables and calculated the differences in the Akaike information criterion (AICC, Burnham and Anderson 2002) scores between each model and the null model (dredge function, R-package MuMIn). We also calculated the Akaike weights for each model (model.avg function, R-package MuMIn). Finally, we selected the best two-variable models. Since our aim was to highlight habitat variables as bioindicators and not to explain taxonomic communities, we did not account for a priori ecological links between the taxon and the habitat variables.

Furthermore, we checked the significant relationships (at $p<0.01$ ) between habitat variables and species richness in the GLMM for thresholds. Threshold values were calculated by recursive partitioning and derived from estimates of breakpoints by means of maximally selected two-sample statistics (Hothorn and Hornik 2006; ctree function, R-package party). This method provides a conditional inference tree with $p$-values for one or more critical thresholds. When using the ctree function, the model is constrained and does not allow any co-variables or random effects to be taken into account. To deal with this issue, we kept only the most significant results: only primary nodes 
213 with highly significant $(p<0.001)$ thresholds were selected, and only if the number of plots was

214 greater than 30 on either side of the threshold. Then, 95\% confidence intervals (bootstrap percentile

215 interval) were calculated for all the selected thresholds, based on 1,000 bootstrap samples (boot.ci

216 function, R-package boot).

217 In order to standardize sampling effort and to account for missing data for saproxylic beetles, ground

218 beetles and hoverflies (traps destroyed by animals, wind, rain or humans), we used the log of a

219 corrected factor based on the number of undisturbed sampling months as an offset in our models.

220 For vascular plants, we considered the data to be comparable whatever the area sampled (ranging

221 from 600 to $1018 \mathrm{~m}^{2}$ ) since (i) the observers took care to maintain homogeneous local conditions

222 (phytosociological-type sampling), (ii) in forest types similar to those we sampled, Archaux et al.

223 (2007) highlighted samplings set up on areas above $400 \mathrm{~m}^{2}$ are comparable, and (iii) the sampled

224 surface area was constant in each forested area (used as a grouping variable in the models). Fungi

225 were sampled along a gradient of one to three years, with one to three runs per year; we therefore

226 only retained polypore records in our analysis, since their sporophores are long-lasting. Bird data was

227 recorded inside 25, 100, and outside 100 m-radius areas; since environmental variables were

228 recorded on $56 \mathrm{~m}$-radius plots (i.e. 1-ha plots), only bird data recorded inside a $25 \mathrm{~m}$-radius area

229 were retained (see Table A1 for details).

230

\section{3. Results}

232 3.1. Variations in species composition

233 Habitat variations significantly $(p<0.01)$ reflected variations in species composition for vascular plants 234 and saproxylic beetles, and to a lesser level of significance $(p<0.05)$ for polypores, bats and lichens.

235 However, they did not reflect variations in species composition for ground beetles, birds, bryophytes 236 or hoverflies (Table 2).

237

238 Table 2. Procrustes analysis of the inter-plot congruence in fit between species and habitat

239 dissimilarity matrices; permutation tests were conditioned on forested area; Procrustes test

240 significance: ${ }^{* *}: 0.001<p<0.01 ;{ }^{*}: 0.01<p<0.05$; ns=non-significant. Procrustes metrics $=$ symmetric

241 Procrustes sum of squares between matrices (m12), derived by the Procrustes rotation method in

242 correlation-like statistics

\begin{tabular}{lll} 
Taxon & Procrustes metrics & p-value \\
\hline Vascular plants & 0.623 & $* *$ \\
Lichens & 0.807 & $*$ \\
Bryophytes & 0.786 & ns
\end{tabular}




$\begin{array}{lll}\text { Polypores } & 0.902 & * \\ \text { Saproxylic beetles } & 0.855 & * * \\ \text { Ground beetles } & 0.831 & \mathrm{~ns} \\ \text { Hoverflies } & 0.929 & \mathrm{~ns} \\ \text { Birds } & 0.924 & \mathrm{~ns} \\ \text { Bats } & 0.940 & *\end{array}$

3.2. Habitat variables as indicators of biodiversity

246 3.2.1. Relationships between habitat variables and species composition for full taxa

247 Individual habitat variables did not contribute very much (from 0.46 to $58.03 \%$ ) to variations in

248 species composition (total inertia) as estimated by CAP (Table A4). However, when we tested the

249 whole set of nine recorded variables (or 10 if ancientness could be determined), excluding the

250 "forested area" random effect, contributions ranged from $6.05 \%$ (for saproxylic beetles) to $88.33 \%$ of

251 the total inertia (for lichens) (Table A4, last column).

252 We found numerous significant relationships between habitat variables and species composition (Fig.

253 2; details in Table A4). Vascular plants, saproxylic beetles and polypores showed the largest

254 proportion of significant relationships tested $(100 \%, 100 \%$ and $80 \%$, respectively, at $p<0.05)$. On the

255 other hand, we did not find any significant relationships between habitat variables and bats (Table

256 A4). However, the set of habitat variables contributed to $9.5 \%$ of bat inertia.

257

258

259

260 


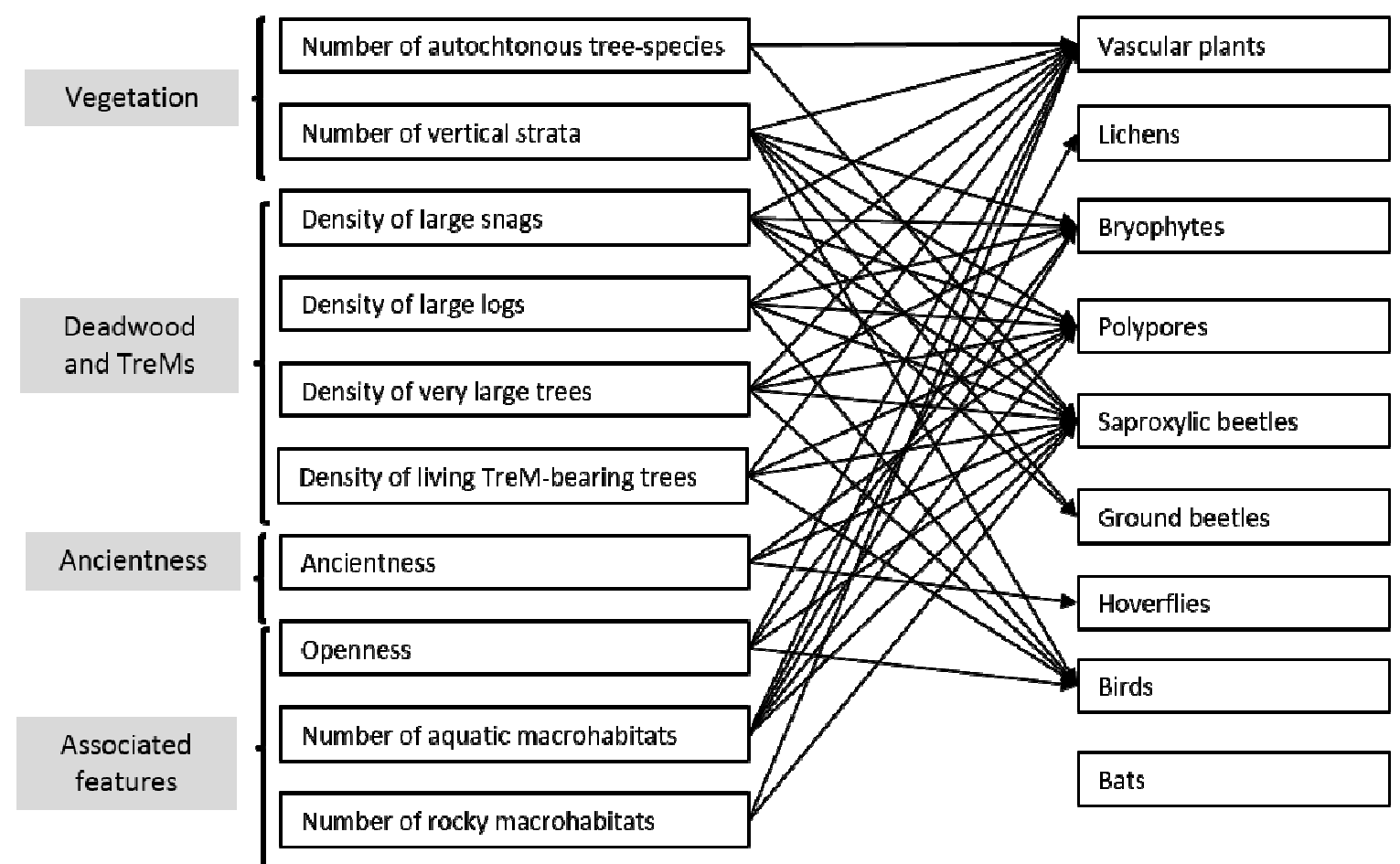

Figure 2. Relationships between the ten habitat variables (left) and inter-plot variation in species composition (right) for nine taxa (full groups) at the plot scale; only significant relationships at $p<0.01$ are shown (solid arrows); TreMs: tree-related microhabitats; ancientness was tested for only saproxylic beetles, ground beetles, hoverflies and polypores since sampling was unbalanced for the other taxa

\subsubsection{Relationships between habitat variables and species richness for full taxa}

At the plot scale, the 10 IBPvariables taken separately had fewer significant effects on species richness than on species composition ( $n=31$ and $n=49$, respectively at $p<0.05$; Table A4 for species composition \& A5 for species richness). However, most of the habitat variables showed significant relationships with the species richness of at least one of the taxa (at $p<0.01 ;$ Fig. 3). We observed more positive relationships than negative ones ( $n=23$ and $n=7$, respectively, at $p<0.05$ ). Only vascular plants, bryophytes and saproxylic beetles showed significant relationships with the covariables.

275 Whenthe whole set of habitat variables was considered $(\mathrm{N}=17)$, saproxylic beetles, bats, and 276 hoverflies showed the largest number of significant relationships ( $n=10,7$ and 7 , respectively, at $277 p<0.05$ ), while lichens showed only two. The best determining habitat variables (at $p<0.001)$ on 278 species richness were (Table A5): (i) the number of vertical strata on ground beetles (-) and hoverflies 279 (+); (ii) the density of large snags on bryophytes (+); (iii) the density of large logs on bryophytes (+); 
(iv) the density of trees with crown deadwood on hoverflies (-); (v) the density of polypore-bearing

281 trees on polypores (+); (vi) the density of trees with missing bark on both polypores $(+)$ and hoverflies

$282(+)$; (vii) the density of cracks on saproxylic beetles (+); (viii) openness on both vascular plants (+) and 283 saproxylic beetles (+); (ix) the number of aquatic macrohabitats on vascular plants (+), polypores (+) and saproxylic beetles $(+)$; and $(x)$ the number of rocky macrohabitats on saproxylic beetles $(+)$.

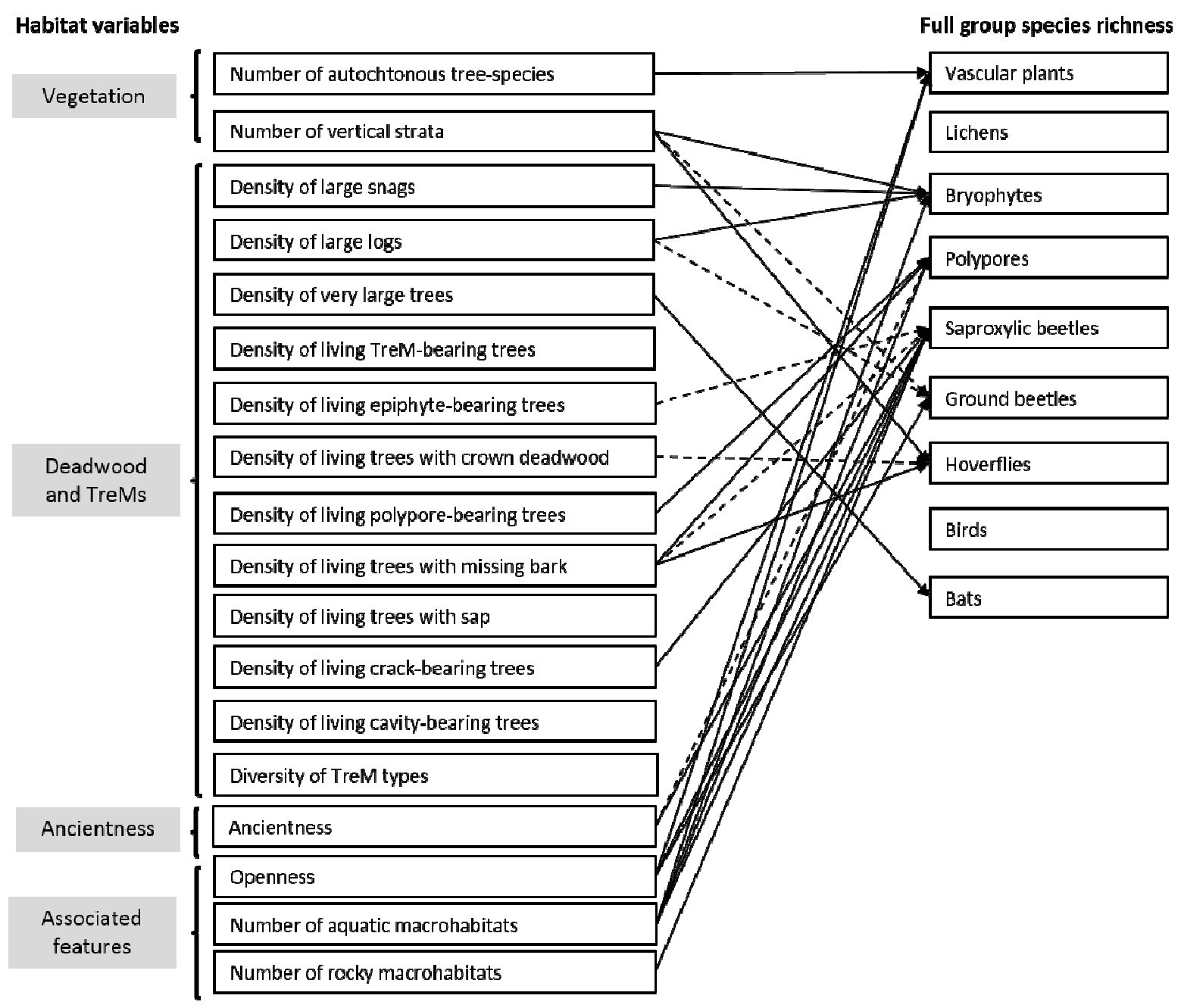

Figure 3. Relationships at the plot scale between 18 habitat variables and the species richness of 9 taxa (full groups); significant relationships at $p<0.01$ are shown by solid or dashed arrows for positive and negative relationships, respectively; TreMs: tree-related microhabitats; ancientness was tested only for saproxylic beetles, ground beetles, hoverflies and polypores since sampling was unbalanced for the other taxa increasing altitude, non-Atlantic geographical location and dominance of broadleaves (Table A5). 
Increasing altitude also had a positive effect on the species richness of bryophytes while it had a negative effect on that of vascular plants.

The two most common habitat variables in the best two-variable models for species richness were number of tree-species $(n=5)$ and number of aquatic macrohabitats $(n=5)$ (Table 3 ). The best model for saproxylic beetle diversity included only covariables.

Table 3. Best models (GLMM; max. 2 terms) for the alpha-diversity of nine full taxa and four forest subgroups; forested area was a random variable; see Table 1 for abbreviations

\begin{tabular}{|c|c|c|}
\hline Taxon & Best model (AICc) & AIC null model \\
\hline Vascular plants & alt + nb.aqua (1262.50) & 1296 \\
\hline Forest vascular plants & nb.aqua + nb.ts $(961.8)$ & 1014.4 \\
\hline Lichens & nb.roch + nb.strata (165.87) & 168.91 \\
\hline Bryophytes & nb.aqua + nb.logs (819.20) & 843.41 \\
\hline Polypores & nb.aqua + nb.fungi (914.03) & 946.97 \\
\hline Saproxylic beetles & decidconif + domain (3173.50) & 3305.5 \\
\hline Ground beetles & nb.logs+nb.strata (907) & 939.60 \\
\hline Forest ground beetles & nb.aqua +nb.fun (914.03) & 1188.90 \\
\hline Hoverflies & alt + nb.pdw (1161.10) & 1188.90 \\
\hline Forest hoverflies & nb.ts+ nb.sap (787.55) & 798.85 \\
\hline Birds & nb.ts+ nb.vlt (672.88) & 681.21 \\
\hline Forest birds & nb.ts+nb.vlt (666.55) & 675.05 \\
\hline Bats & nb.ts +nb.vlt (480.92) & 488.17 \\
\hline Forest bats & nb.snags +nb.roch (405.25) & 406.44 \\
\hline
\end{tabular}

Briefly, the habitat variables with the highest number of significant $(p<0.05)$ effects on taxa (full groups) were: (i) for species composition, the density of large snags $(n=8)$, the density of large logs $(n=6)$, the density of very large trees $(n=6)$, the number of vertical strata $(n=6)$, the number of aquatic macrohabitats $(n=6)$, the density of TreM-bearing trees $(n=5)$, and openness $(n=5)$; and (ii) for species richness, the number of vertical strata $(n=5)$, the number of aquatic macrohabitats $(n=5)$ and the density of large logs ( $n=4)$. Except for lichens, hoverflies, birds and bats, we found at least one significant $(p<0.01)$ habitat driver

314 for every taxon, both for species richness and composition (Fig. A1; details in Tables A4 and A5).

315 Among these significant habitat drivers, only five affected two or more taxa: (i) the number of 316 vertical strata for bryophytes and ground beetles, (ii) the number of large snags for bryophytes and 317 saproxylic beetles, (iii) ancientness for polypores and saproxylic beetles, (iv) openness for vascular 
318 plants and saproxylic beetles, and (v) the number of aquatic macrohabitat types for vascular plants,

319 bryophytes, polypores and saproxylic beetles.

3.2.3. Relationships between habitat variables and forest species richness and composition Unexpectedly, most of the forest subgroups showed fewer significant relationships with habitat variables than did the full-groups. This was true for both species richness and composition (Fig. A2 for species composition, Fig. A3 and Table A5 for species richness). Only forest vascular plant species composition showed a number of significant relationships similar to the corresponding full group.

327 Furthermore, as with the full taxonomic groups, none of the habitat variables significantly affected all 328 the forest groups combined, either in terms of species richness or species composition. The density of large logs and openness had a significant effect on the species composition of three out of the four forest groups (namely forest vascular plants, forest birds and forest ground beetles). Only forest birds showed the same best 2-term models for species richness as the related full group (Table 3). We did not reveal any clear driver for forest bats for either species richness or species composition.

3.3.2. Significant thresholds for the relationships between habitat variables and variations in species richness

336 We found seven significant $(p<0.001)$ threshold values at the 1 ha-plot scale for the following positive

$337(+)$ or negative $(-)$ significant $(p<0.01)$ relationships between habitat variables and the species richness of the 14 studied taxonomic groups (Table 4 and Fig. A4, A5, A6, A7, A8 and A9). (i) Vascular plants gained $50 \%$ in species richness above four autochtonous tree species. (ii) Forest vascular plant species richness gained 77\% above four autochtonous tree species. (iii) Bryophyte species richness gained $15 \%$ above three large logs. (iv) Polypore species richness gained $340 \%$ above one aquatic macrohabitat. (v) Forest ground beetle species richness gained $40 \%$ above one polypore-bearing tree. (vi) Forest ground beetle species richness gained $75 \%$ above one tree with missing bark. Finally, 
347 Table 4. Significant thresholds $(p<0.001)$ in positive relationships between habitat variables and

348 taxon species richness at the 1ha-plot scale (see Table A5); Magnitude: relative increase/decrease

349 between median values below and above the threshold; $\mathrm{Cl} 95$ : confidence interval at 95\% (5,000

350 bootstrap samples); $d=$ diameter, $d b h=$ diameter at breast height, TreM=tree-related microhabitat

\begin{tabular}{|c|c|c|c|c|c|}
\hline Variable & Taxon & Thresholds [Cl 95] & $\begin{array}{l}\text { Medians below/above } \\
\text { the threshold ( } \mathrm{nb} \text { of } \\
\text { plots) }\end{array}$ & Magnitude & $\begin{array}{l}\text { Synthesis for an } \\
\text { integrated } \\
\text { management strategy }\end{array}$ \\
\hline $\begin{array}{l}\text { Number of autochtonous } \\
\text { tree species }\end{array}$ & Vascular plants & $4[4-6]$ & $26(n=47) / 39(n=100)$ & $+50 \%$ & $\begin{array}{l}\mathrm{N} \geq 4 \text { : significant } \\
\text { increase in species } \\
\text { richness for vascular } \\
\text { plants }\end{array}$ \\
\hline $\begin{array}{l}\text { Number of autochtonous } \\
\text { tree species }\end{array}$ & $\begin{array}{l}\text { Forest vascular } \\
\text { plants }\end{array}$ & $4[4-5]$ & $13(n=47) / 23(n=100)$ & $+77 \%$ & $\begin{array}{l}\mathrm{N} \geq 4 \text { : significant } \\
\text { increase in species } \\
\text { richness for forest } \\
\text { vascular plants }\end{array}$ \\
\hline $\begin{array}{l}\text { Density of large logs }(d \geq 40 \\
\mathrm{cm} \text { ) }\end{array}$ & Bryophytes & $3[2-12]$ & $13(n=59) / 15(n=83)$ & $+15 \%$ & $\begin{array}{l}\mathrm{N} \geq 3 \text { : significant } \\
\text { increase in species } \\
\text { richness for } \\
\text { bryophytes }\end{array}$ \\
\hline $\begin{array}{l}\text { Number of types of aquatic } \\
\text { habitats }\end{array}$ & Polypores & $1[0-1]$ & $5(n=126) / 17(n=31)$ & $+340 \%$ & $\begin{array}{l}\mathrm{N} \geq 1 \text { : significant } \\
\text { increase in species } \\
\text { richness for polypores }\end{array}$ \\
\hline $\begin{array}{l}\text { Density of living polypore- } \\
\text { bearing trees }\end{array}$ & $\begin{array}{l}\text { Forest ground } \\
\text { beetles }\end{array}$ & $1[0-1]$ & $5(n=97) / 7(n=76)$ & $+40 \%$ & $\begin{array}{l}\mathrm{N} \geq 1 \text { : significant } \\
\text { increase in species } \\
\text { richness for forest } \\
\text { ground beetles }\end{array}$ \\
\hline $\begin{array}{l}\text { Density of living trees with } \\
\text { missing bark }\end{array}$ & $\begin{array}{l}\text { Forest ground } \\
\text { beetles }\end{array}$ & $1[0-1]$ & $4(n=41) / 7(n=132)$ & $+75 \%$ & $\begin{array}{l}\mathrm{N} \geq 1 \text { : significant } \\
\text { increase in species } \\
\text { richness for forest } \\
\text { ground beetles }\end{array}$ \\
\hline Number of vegetation strata & Ground beetles & $3[2-3]$ & $26(n=43) / 8(n=127)$ & $-69 \%$ & $\begin{array}{l}\mathrm{N} \geq 3 \text { : significant } \\
\text { decrease in species } \\
\text { richness for ground } \\
\text { beetles }\end{array}$ \\
\hline
\end{tabular}

\section{Discussion}

355 Among the numerous results relating the species composition and diversity of the studied taxonomic

356 groups to the selected environmental variables, most were expected. However, a few were

357 surprising in ecological terms. For example, we found positive relationships between saproxylic

358 beetle species richness and the number of aquatic and rocky macrohabitats. However, aquatic and

359 rocky macrohabitats often result in a higher degree of stand openness when they occur, and we

360 show that openness favors higher saproxylic beetle species richness. The negative relationship

361 between hoverfly species richness and the density of trees with crown deadwood was equally

362 surprising since several hoverfly species do use crown deadwood during their larval stage (Speight et 
al. 2015). These results may be due to the systematic selection of the explanatory variables we applied to our models, which we did not base on ecological hypotheses; or by indirect effects related to more efficient sampling of hoverflies with our flight interception traps in open stands than under a dense canopy. Higher hoverfly species richness has been observed in open stands (Gittings et al. 2006). Indeed, more open stands provide the species-rich herb layer adult hoverflies need as a source of pollen and nectar (Fayt et al. 2006), although several forest species are saproxylic at the larval stage and often depend on various saproxylic substrates in mature closed-canopy stands (see also Herrault et al. 2016).

371

4.1. Using species composition vs species richness to highlight habitat surrogates Most of the previous studies dealing with the relationships between habitat variables and taxa have focused on species richness alone (Gao et al. 2015). However, we found more significant relationships between habitat variables and species composition than between habitat variables and species richness. Only $16 \%$ of the tested relationships were significant (at $p<0.01$ ) for both species richness and composition. This confirms that species composition is relevant when selecting biodiversity surrogates and investigating the relationships between biodiversity and habitat variables. Indeed, species composition provides results complementary to those obtained through a species-richness approach for cross-taxon congruence (Larrieu et al. 2018; Jokela et al. 2018). However, species composition is slightly more difficult to interpret than species richness, especially in terms of the magnitude of the relationship. Alternative approaches, not pursued here, include using more precise ecological subgroups (Barbier et al. 2009; Gosselin 2012; Zilliox and Gosselin 2014) or performing analyses at the species level (Okland et al. 1996; Bouget et al. 2014b). However, the practical comprehensive life-trait databases required by such approaches are available for very few taxa (e.g. Syrph the Net for hoverflies; Speight et al. 2015) and most life-trait descriptions must therefore be collected from a variety of dispersed sources. Most of the relationships we found between the habitat variables and species richness were positive (77\%). However, the number of vertical strata, the density of large logs, the density of trees with missing bark and ancientness showed both positive and negative relationships, depending on the taxon.

394 We found that the density of large logs was a relevant variable for the species richness of corticolous and saproxylic bryophytes, which is partly in line with Söderström (1988a, b), Andersson and 
Hytteborn (1991) and Sabovljevic et al. (2010) who revealed a positive relationship between log

397 diameter and the frequency of saproxylic bryophytes. We also revealed that the density of large

398 snags was a relevant indicator for the species richness of corticolous and saproxylic bryophytes,

399 although snags had previously been highlighted as a bryophyte-poor substratum (Lõhmus et al. 2007)

400 less crucial than logs for this taxon (Humphrey et al. 2002). Finally, Tönnberg (2001) found no

401 correlation between the local amount of deadwood and the species richness of saproxylic

402 bryophytes. We therefore conclude that focusing on any large deadwood items (both logs and snags)

403 may be a simpler yet efficient way to check for bryophyte diversity with a view to conservation.

404 Ancientness is known to influence assemblage composition for true bugs (Gossner et al. 2008),

405 ectomycorhizic fungi (Diedhiou et al. 2009), soil fauna (Janssen et al. 2018) and - among the taxa in

406 this study - vascular plants (e.g. Hermy and Verheyen 2007; Dupouey et al. 2002), ground beetles

407 (Assmann 1999), saproxylic beetles (Brin et al. 2016; Janssen et al. 2016, 2017), hoverflies (Herrault

408 et al. 2015), bryophytes and epiphytic lichens (Rose 1993; Fritz et al. 2008; Janssen et al. 2019).

409 Unfortunately, we were not able to test for an ancientness effect on the species composition of

410 bryophytes, lichens, bats, birds and vascular plants since our sampling design was very unbalanced.

411 However, like Herrault et al. (2015), we found that ancientness was a key feature for species

412 composition in hoverflies for the full group (but not for forest-specialists alone). Contrary to Assmann

413 (1999), we did not find that ancientness influenced ground beetle assemblages. Finally, we found

414 that ancientness is relevant for the species richness of polypores, though unexpectedly, the

415 relationship was negative. To our knowledge, this is an original result. However, it should be noted

416 that our sampling design had a high proportion of young stands hosting pioneer tree species, which

417 can quickly provide saproxylic substrates due to their short lifespan, thus promoting high polypore

418 diversity. Although we found lower polypore species richness in ancient forests, the highly significant

419 relationship between ancientness and the composition of polypore assemblages showed that this

420 factor does play a role in fungus conservation by promoting specific species.

421

422 The variable "number of autochthonous tree-species" occurred in $36 \%$ of our best models for species

423 richness. This relationship was expected for vascular plants since i) species richness for non-woody

424 plants, shrubs and trees are all positively influenced by the nutrient richness of the soil (e.g. Rameau

425 et al. 1999) and ii) both tree seedlings and small saplings are commonly included in the vascular plant

426 sample. A similar relationship was also expected for forest hoverflies, bats and birds since a stand

427 encompassing a mix of tree species provides a wider range of both feeding resources for hoverfly

428 larvae and resting and breeding microsites for bats and birds than does a pure stand. Mixed stands 
better match the requirements of different taxa (e.g. Cramp et al. 1980; Arthur and Lemaire 2009;

430 Speight et al. 2015).

431 The variable "number of aquatic macrohabitats" occurred in $36 \%$ of our best models for species

432 richness and was relevant for the species composition of six out of nine taxa (full groups). This type

433 of habitat is often considered specific to aquatic taxa only, whereas our findings suggest that aquatic macrohabitats could be more widely used as an indirect indicator of wet conditions in general.

4.3. Most of the forest taxonomic subgroups showed weaker relationships with habitat variables than did full-groups

We built forest subgroups for bats, birds, hoverflies, ground beetles and vascular plants since (i) forest-specialist species are often targeted for conservation by forest managers who use an integrated approach, and (ii) we expected stronger relationships than for the full groups since the latter encompass species ranging beyond forest conditions. However, we found more numerous significant relationships between full groups and habitat variables than we did for forest subgroups alone. Several reasons may explain this result. First, the life-trait databases or the variables we used to build our forest subgroups may not have been completely relevant. For example, dwelling in cavities or under peeling bark may not be the most relevant feature for forest-specialist bats, very few of which are strict tree-roosters; most also make use of similar microhabitats provided, for instance, by buildings (Arthur and Lemaire 2009). Secondly, forest specialists may mainly depend on habitat variables we either did not record or recorded too broadly (i.e. our variables may not have focused on features specific enough to definitely select the forest specialist), or which we did not record at the most appropriate spatial scale. Thirdly, taxa such as hoverflies are multi-habitat users, i.e. saproxylic species need deadwood substrates while all adults need flower resources (Speight et al. 2015). This means that the presence of saproxylic hoverflies is mostly linked to the co-occurrence of both deadwood and flowering plants in the same stand. Another explanation might be that only a part of the habitat feature is included in the IBP variables; for example, only deadwood items over 40 $\mathrm{cm}$ in diameter are recorded and, although these large items are crucial for biodiversity (e.g. Gossner et al. 2013), most saproxylic species require a wider range of diameters. Finally, the relationship with the non-forest species in the full group may have actually been stronger than with the forest specialists.

459 Stronger relationships between habitat variables and non-forest vascular plants than with forest 460 vascular plants have already been found (Barbier et al. 2009; mostly Zilliox and Gosselin 2014). 
Among bryophytes, forest-specialists do seem to have stronger relationships with forest habitat variables than do the other species in the taxon (Gosselin et al. 2014). Yet a practical life-trait database relevant for France is lacking since the databases available in Europe to date are limited to the UK (Hill 2007) and Germany (Schmidt 2013).

\subsection{From ecological results to forest management guidelines: providing thresholds} When we analyzed our species richness models in terms of the magnitude of the relationships (as in e.g. Barbier et al. 2009 and Zilliox \& Gosselin 2014), we found rather strong relationships between habitat variables and species composition, and weak (though sometimes significant) relationships between habitat variables and species richness, with one notable exception (the relationship between the number of strata and hoverfly species richness). Yet, threshold analyses revealed some strong, non-linear relationships between certain habitat variables and species richness for some taxa. Forest management encompasses a wide range of technical, economic and environmental aspects, and covers a wide array of disciplines. Therefore, managers are often faced with complex trade-offs. Simple and efficient guidelines can help them better integrate biodiversity issues in both management plans and technical procedures. Critical thresholds for taxon response to habitat variations are among the simplest tools (Müller and Bütler 2010). Significant thresholds at the stand scale for crucial deadwood amounts (Müller and Bütler 2010; Gossner et al. 2013), optimum range of canopy openness, proportion of deciduous trees and optimum stand age (Moning and Müller 2008, 2009) have already been published for snails, birds, saproxylic beetles, fungi, mosses and lichens. In our case, we did not record stand age since most of the stands we sampled were uneven-aged. For deadwood, we used a complementary approach. First, we chose density rather than total volume for deadwood items since assessing density does not require measurements or calculations and is easier for occasional forest managers (e.g. owners of small woodlands) to use. Second, we focused on particular features such as large deadwood items or very large trees, which are typically rare in managed forests (Bauhus et al. 2009, Paillet et al. 2015) yet are relevant for saproxylic beetles (Gossner et al. 2013), fungi or forest bryophytes (Gosselin et al. 2014, 2017), among others. We provide seven significant thresholds. Among them, five thresholds seem to be related to ecological requirements: the number of autochtonous tree species for vascular plants (both full- and forest subgroup; positive relationship; see discussion above), the density of large logs for bryophytes (as crucial substrates; positive relationship), the number of aquatic macrohabitats for polypores (positive relationship; probably because wet conditions favor the growth of fungi), and the number of vegetation strata for ground beetles (negative relationship; ground beetles are mostly heliophilous 
and mainly associated to non-forest ecosystems). The two others, i.e. the density of living polyporebearing trees and trees with missing bark for forest ground beetles, are likely to hide correlations with other ecological factors, and this may reduce their relevance in contexts outside the range of forest types we studied.

Gosselin et al. (2014) showed that using other statistical methods (taking into account random effects, specific probability distribution, spatial autocorrelation and other continuous sigmoid functions) led to larger confidence intervals around thresholds. Furthermore, an ongoing study highlights that variations in threshold values among forest sites (and also the curve pattern) may have an impact on estimations of the magnitude of the relationships (Godeau et al. submitted). As in Gosselin et al. (2014) and Godeau et al. (submitted), the inclusion of non-linear relationships allowed us to detect strong relationships with species richness, while the use of (generalized) linear models only mostly revealed only weak relationships. Further research should therefore focus on properly estimating thresholds and non-linear relationships between habitat variables and biodiversity metrics for a large range of taxa and forest contexts. However, since we used highly demanding criteria and kept only the most significant thresholds, we are confident that our thresholds are relevant for the conservation of the concerned taxa in temperate forests.

\subsection{How to deal with only a few weak relationships between habitat variables and biodiversity} The Procrustes approach showed that the ten IBP habitat variables considered together were relevant when assessing variations in species composition for five of the nine taxa studied (56\%). Further research should consider variations in functional diversity and use taxon life-traits in order to evaluate whether the variations in species composition are related to functional changes. It would also be relevant to test covariations on key taxa for ecosystem functioning such as soil-dwellers (e.g. Zanella et al 2017). Managers would respond more readily to demands for biodiversity preservation if the changes they implement resulted in better ecosystem functioning.

This study highlights numerous significant relationships between individual habitat variables and biodiversity and provides practical thresholds for management. However, none of the habitat variable combinations consistently explained the variations in species richness for all the taxa studied. Furthermore, the contribution of the habitat variables to total species composition inertia was relatively low (median=10.4\%, mean=15.9, range: 6-88\%). The limited explanatory power of our environmental indicators for biodiversity can be linked to several effects. First, nonlinear effects may 
527 be at play (Araujo et al. 2003); this is consistent with our findings that threshold non-linear models

528 gave stronger relationships than did generalized linear models for species richness. Second, the

529 suitable niches might not have been fully occupied due to time-lag responses (Cristofoli and Mahy

530 2010; Jackson and Sax 2010). In addition, non-environmental factors may have been predominant

531 biodiversity drivers (Hortal et al. 2009). Finally, our taxonomic samplings could have been

532 incomplete, or other environmental factors not considered in our study could have been involved.

533

534

535

536

537

538

539

540

541

542

543

544

545

546

547

548

549

550

551

552

553

554

555

556

557

558

559

\section{Conclusion and research perspectives}

It is relevant in a funds-limited context to consider an indicator in terms of both performance and cost. Environmental indicators are easy to assess during routine management activities and are the cheapest indicators for species richness in Mediterranean ecosystems (Mandelik et al. 2010).

Furthermore, recording taxonomic data is time-consuming and costly, even though it is possible to pre-select taxa by optimizing the cost/performance ratio (Gardner et al. 2008; Larrieu et al. 2018). Schamberger (1988) and Noss (1990) believe that monitoring both habitat and taxa is essential in most cases. Landres et al. (1988) also recommend mixing taxonomic and environmental indicators while Ferris and Humphrey (1999) suggest using a combination of several structural and compositional indicators. Composite data sets combining both taxonomic and environmental data have already demonstrated their efficiency and have led to progress in biodiversity protection (Pressey 2004; Cowling et al. 2004). To go further, Vierikko et al. (2010) suggest using a combination of taxonomic, environmental and socio-economic indicators to monitor sustainable forestry goals. According to Duelli and Obrist (2003), an index combining a set of indicators is the best approach. Based on the combined results of this study and those of a companion study assessing cross-taxon congruence patterns and the cost-efficiency of surrogate taxa (Larrieu et al. 2018), we propose the following recommendations to help forest managers promote more biodiversity-friendly forest management: (i) routinely apply a rapid habitat assessment such as the IBP; (ii) use appropriate silvicultural techniques to increase or maintain autochtonous tree diversity and the density of large logs above the thresholds highlighted in this study; (iii) conserve the diversity of aquatic habitats; and (iv) periodically carry out a biodiversity assessment at the forest scale by recording taxonomic data focusing on saproxylic beetles and vascular plants, or on saproxylic beetles, vascular plants and birds (the most cost-efficient associations, according to Larrieu et al. 2018).

Due to the wide range of taxa and forest types sampled in this study, we believe our findings and recommendations are relevant at the stand scale for temperate European forests. However, further 
560

561

562

563

564

565

566

567

568

569

570

571

\section{2}

573

574

575

576

577

578

579

580

581

582

research would be welcome since (i) most of our taxonomic data are related to a single sampling year; ii) habitat variables were only recorded at the stand scale (landscape-level environmental variables should also be recorded); (iii) only one metric was used to evaluate alpha diversity (i.e. species richness); (iv) we used presence/absence data to be consistent among the taxa but adding abundance data could be beneficial; and (v) statistical analyses could be improved (e.g. non-linear approaches, consideration of more random effects). Research should also consider broader temporal (Favreau et al. 2006) and spatial scales (Yoccoz et al. 2001, Bouvier et al. 2017) as well as take into account adjacent habitats and their management, in particular for small woodlands (Tölgyesi et al. 2018). Research should also consider some poorly-known and very diverse taxa, which play a key role in ecosystem functioning, such as soil fauna, Diptera other than hoverflies, moths, fungi other than polypores and parasitoid Hymenoptera.

\section{Acknowledgements}

This research was partly funded by the French Ministry in charge of the Ecology through the "Biodiversité, Gestion Forestière et PolitiquesPubliques" (BGF) program (convention 10-MBGD-BGF1-CVS-092, n.CHORUS 2100214 651), and through the DEB-Irstea convention (GNB-Valo action). The French Environment and Energy Management Agency (ADEME) as well as European (FEDER) and French grants (Conseil Régional de Midi-Pyrénées) also contributed. We are indebted to B. Nusillard, A. Lassauce, Y. Dumas, Y. Paillet, C. Moliard (Irstea), T. Barnouin, T. Noblecourt, F. Soldati, H. Voiry (ONF), A. Brin, H. Brustel, L. Valladares (EIP), J. Willm, L. Burnel (INRA), J.P. Sarthou (INRA), V. Sarthou (Syrphys) and all the local forest managers (private and public, from ONF and RNF) for their field and laboratory work and for access to databases. We thank V. Moore who reviewed the English manuscript and the reviewers who provided insightful comments to improve the manuscript. 
585 Andersson, L. I., Hytteborn, H., 1991. Bryophytes and decaying wood - a comparison between 586 managed and natural forest. Holarctic Ecology 14 (2): 121-130.

587

588

589

590

591

592

593

594

595

596

597

598

599

600

601

602

603

604

605

606

607

608

Anderson, M.J., Willis, T.J., 2003. Canonical analysis of principal coordinates: a useful method of constrained ordination for ecology. Ecology 84, 511-525.

Araujo, M. B., Densham, P., Humphries, C., 2003. Predicting species diversity with ED: the quest for evidence. Ecography 26 (3), 380-383.

Archaux, F., Bergès, L., Chevalier, R., 2007. Are plant censuses carried out on small quadrats more reliable than on larger ones? - Plant Ecology 188 (2): 179-190.

Arthur, L., Lemaire, M., 2009. Les chauves-souris de France, Belgique, Luxembourg et Suisse Biotope, Mèze (collection Parthénope). MNHN, Paris.

Assmann, T., 1999. The ground beetle fauna of ancient and recent woodlands in the lowlands of north-west Germany (Coleoptera, Carabidae), Biodivers. Conserv. 8: 1499-1517.

Barbier, S., Chevalier, R., Loussot, P., Bergès, L., Gosselin, F., 2009. Improving biodiversity indicators of sustainable forest management: tree genus abundance rather than tree genus richness and dominance for understory vegetation in French lowland oak hornbeam forests. Forest Ecology and Management 258, S176-S186.

Bauhus, J., Puettmanna, K., Messier, C., 2009. Silviculture for old-growth attributes. Forest Ecology and Management 258 (4), 525-537.

Blondel, J., Ferry, C., Frochot, B., 1970. La méthode des indices ponctuels d'abondance I.P.A. ou des relevés d'avifaune par "points d'écoute". Alauda 38, 55-71.

Bouget, C., Larrieu, L., Nusillard, B., Parmain, G., 2013. In search of the best local habitat drivers for saproxylic beetle diversity in temperate deciduous forests. Biodivers Conserv. 22, 2111-2130.

Bouget, C., Larrieu, L., Brin, A., 2014a. Key features for saproxylic beetle diversity derived from rapid habitat assessment in temperate forests. Ecological Indicators 36, 656-664. 
Bouget, C., Parmain, G., Gilg, O., Noblecourt, T., Nusillard, B., Paillet, Y., Pernot, C., Larrieu, L., Gosselin, F., 2014b. Does a set aside conservation strategy help the restoration of old-growth attributes and the recolonization of saproxylic beetles? Animal Conservation 17, 342-353.

Bouvier, M., Durrieu, S., Gosselin, F., Herpigny, B., 2017. Use of Airborne Lidar Data to Improve Plant Species Richness and Diversity Monitoring in Lowland and Mountain Forests. PLOS One 12 (9), e0184524.

Brin, A., Valladares, L., Ladet, S., Bouget, C., 2016. Effects of forest continuity on flying saproxylic beetle assemblages in small woodlots embedded in agricultural landscapes. Biodiversity and Conservation 25 (3), 587-602.

Burnham, K.P., Anderson, D.R., 2002. Model selection and multimodel inference, Second ed.: New York: Springer-Verlag.

Coulon, J., Marchal, P., Pupier, R., Richoux, P., Allemand, R., Genest, L.C., Clary, J., 2000. Coléoptères De Rhône-Alpes: Carabiques Et Cicindèles. Museum d'Histoire Naturelle de Lyon et Société Linnéenne de Lyon, Lyon, 390 pp.

Cowling, R. M., Knight, A. T., Faith, D. P., Ferrier, S., Lombard, A. T., Driver, A., Rouget, M., Maze, K., Desmet, P. G., 2004. Nature conservation requires more than a passion for species. Conservation Biology 18 (6), 1674-1676.

Cramp, S. (coord.), 1980. The birds of the western paleartic. Handbook of the Birds of Europe the Middle East and North Africa Vol. I-IX Oxford University Press, New York (1994).Cristofoli, S., Mahy, G., 2010. Colonisation credit in recent wet heathland butterfly communities. Ins. Cons. and Div. 3, 8391.

Diedhiou, A.G., Dupouey, J.L., Buée, M., Dambrine, E., Laüt, L., Garbaye, J., 2009. Response of ectomycorrhizal communities to past Roman occupation in an oak forest. Soil Biol. Biochem. 41: 2206-2213.

Duelli, P., Obrist, M. K., 2003. Biodiversity indicators: the choice of values and measures. Agriculture, Ecosystems \& Environment 98 (1) : 87-98. 
635

636

637

638

639

640

641

642

643

644

645

646

647

648

649

650

651

652

653

654

655

656

657

658

659

660

Dupouey, J.L., Sciama, D., Dambrine, E., Rameau, J.C., 2002. La végétation des forêts anciennes, Rev. Forest. Fr. 6, 521-532.

Failing, L., Gregory, R., 2003. Ten common mistakes in designing biodiversity indicators for forest policy. Journal of Environmental Management 68, 121-132.

FAO 2015. Sustainable forest management. On line: http://www.fao.org/forestry/sfm/en/

Favreau, J.M., Drew, C.A., Hess, G.R., Rubino, M.J., Koch, F.H., Eschelbach, K.A., 2006.

Recommendations for assessing the effectiveness of surrogate species approaches. Biodivers.

Conserv. 15, 3949-3969.

Fayt, P., Dufrêne, M., Branquart, E., Hastir, P., Pontégnie, C., Henin, J.M., Versteirt, V., 2006.

Contrasting responses of saproxylic insects to focal habitat resources: the example of longhorn beetles and hoverflies in Belgian deciduous forests. J. Insect Conserv. 10, 129-150.

Ferris, R., Humphrey, J. W., 1999. A review of potential biodiversity indicators for application in British forests. Forestry 72 (4): 313-328.

Frank, A.F., 2011. R-hacks: useful bits of code for programming and analysis in R/mer-utils.R., https://github.com/aufrank/R-hacks/blob/master/mer-utils.R,

Fritz, Ö., Gustafsson, L., Larsson, K., 2008. Does forest continuity matter in conservation? A study of epiphytic lichens and bryophytes in beech forests of southern Sweden, Biol. Conserv. 141, 655-668.

Gao, T., Hedblom, M., Emilsson, T., Nielsen, A. B., 2014. The role of forest stand structure as biodiversity indicator. Forest Ecology and Management 330, 82-93.

Gao, T., Nielsen, A.B., Hedblom, M., 2015. Reviewing the strength of evidence of biodiversity indicators for forest ecosystems in Europe. Ecol. Indic. 57, 420-434.

Gardner, T.A., Barlow, J., Araujo, I.S., Ávila-Pires, T.C., Bonaldo, A.B., Costa, J.E., Esposito, M.C., Ferreira, L.V., Hawes, J., Hernandez, M.I.M., Hoogmoed, M.S., Leite, R.N., Lo-Man-Hung, N.F., Malcolm, J.R., Martins, M.B., Mestre, L.A.M., Miranda- Santos, R., Overal, W.L., Parry, L., Peters, S.L., Ribeiro-Junior, M.A., Da Silva, M.N.F., Motta, C., Peres, C.A., 2008. The cost-effectiveness of biodiversity surveys in tropical forests. Ecol. Lett. 11, 139-150. 
661

662

663

664

665

666

667

668

669

670

671

672

673

674

675

676

677

678

679

680

681

682

683

684

685

686

687

Geburek, Th., Milasowszky, N., Frank, G., Konrad, H., Schadauer, K., 2010. The Austrian Forest Biodiversity Index: All in one, Ecological Indicators 10, 753-761.

Gittings, T., O'Halloran, J., Kelly, T., Giller, P.S., 2006. The contribution of open spaces to the maintenance of hoverflies (Diptera, Syrphidae) biodiversity in Irish plantation forests. Forest Ecol. Manag. 237, 290-300.

Godeau, U., Bouget, C., Piffady, J., Pozzi, T., Gosselin, F., (submitted). The importance of being random! Taking full account of random effects in nonlinear sigmoid hierarchical Bayesian models.

Gosselin, F., 2012. Improving approaches to the analysis of functional and taxonomic biotic homogenization: beyond mean specialization. Journal of Ecology 100 (6), 1289-1295.

Gosselin, M., Bouget, C., Archaux, F., Paillet, Y., Boulanger, V., Debaive, N., Gosselin, F., 2017. Projet GNB : synthèse des relations entre naturalité anthropique, naturalité biologique et biodiversité. Rendez Vous Techniques (ONF) $56: 56-64$.

Gosselin, F., Paillet, Y., Gosselin, M., Durrieu, S., Larrieu L., Marrell, A., Lucie, X., Boulanger, V., Debaive, N., Archaux, F, Bouget, C., Gilg, O., Rocquencourt, A., Drapier, N., Dauffy-Richard, E., 2014. Gestion forestière, naturalité et biodiversité (Forest management, naturalness and biodiversity). Biodiversité, Gestion Forestière \& Politiques publiques. Project report, 10 pp.

Gossner, M., Engel, K., Jessel, B., 2008. Plant and arthropod communities in young oak stands: are they determined by site history? Biodivers. Conserv. 17, 3165-3180.

Gossner, M., Lachat, T., Brunet, J., Isacsson, G., Bouget, C., Brustel, H., Brandl, R., Weisser, W.W., Mueller, J., 2013. Current Near-to-Nature Forest Management Effects on Functional Trait Composition of Saproxylic Beetles in Beech Forests. Conservation Biology 27, 605-614.

Herrault, P.A., Larrieu, L., Cordier, S., Gimmi, U., Lachat, T., Ouin, A., Sarthou, J.P., Sheeren, D., 2016. Combined effects of area, connectivity, history and structural heterogeneity of woodlands on the species richness of hoverflies (Diptera: Syrphidae). Landscape Ecology 31 (4): 877-893.

Hermy, M., Honnay, O., Firbank, L., Grashof-Bokdam, C., Lawesson, J.E., 1999. An ecological comparison between ancient and other forest plant species of Europe, and the implications for forest conservation, Biol. Conserv. 91, 9-22. 
688

689

690

691

692

693

694

695

696

697

698

699

700

701

702

703

704

705

706

707

708

709

710

711

712

713

714

Hermy, M., Verheyen, K., 2007. Legacies of the past in the present-day forest biodiversity: a review of past land-use effects on forest plant species composition and diversity. Ecol. Res. 22, 361-371.

Hill, M., Prestion, C., Bosanquet, S., Roy, D., 2007. BRYOATT: Attributes of British and Irish Mosses, Liverworts and Hornworts, With Information on Native Status, Size, Life Form, Life History, Geography and Habitat. NERC; Centre for Ecology and Hydrology (CEH); Countryside Council for Wales, Cambridgeshire, $88 \mathrm{pp}$.

Hortal, J., Araujo, M. B., Lobo, J. M., 2009. Testing the effectiveness of discrete and continuous environmental diversity as a surrogate for species diversity. Ecological Indicators 9 (1): 138-149.

Hothorn, T., Hornik, K.Z.A., 2006. Party: a laboratory for recursive part(y)itioning. Available from http://CRAN.R-project.org.

Humphrey, J.W., Davey, S., Peace, A.J., Ferris, R., Harding, K., 2002. Lichens and bryophyte communities of planted and semi-natural forests in Britain: the influence of site type, stand structure and deadwood. Biological Conservation 107, 165-180.

Jackson, S. T., Sax, D. F., 2010. Balancing biodiversity in a changing environment: extinction debt, immigration credit and species turnover. Trends in Ecology \& Evolution 25 (3): 153-160.

Jansen, A., Robertson, A., Thompson, L., Wilson, A., 2004. Development and application of a method for the rapid appraisal of riparian condition. River and Riparian Land Management Technical Guideline 4, 1-14.

Janssen, P., Cateau, E., Fuhr, M., Nusillard, B., Brustel, H., Bouget, C., 2016. Are biodiversity patterns of saproxylic beetles shaped by habitat limitation or dispersal limitation? A case study in unfragmented montane forests. Biodiversity and Conservation 25 (6): 1167-1185.

Janssen, P., Bec, S., Fuhr, M., Taberlet, P., Brun, J.J., Bouget, C., 2018. Present conditions may mediate the legacy effect of past land-use changes on species richness and composition of aboveand below-ground assemblages. Journal of Ecology 106 (1): 306-318.

Janssen, P., Fuhr, M., Bouget, C., 2019. Beyond forest habitat qualities: climate and tree characteristics as the major drivers of epiphytic macrolichen assemblages in temperate mountains. Journal of Vegetation Science, 30, 1: 42-54 
Janssen, P., Fuhr, M., Cateau, E., Nusillard, B., Bouget, C., 2017. Forest continuity acts congruently with stand maturity in structuring the functional composition of saproxylic beetles. Biological Conservation 205, 1-10.

Jennings, S., Nussbaum, R., Judd, N., Evans, T., 2003. The High Conservation ValueForest Toolkit (Three Volumes). ProForest, Oxford.

Jokela, J., Juutilainen, K., Korpela, L., Kouki, J., Kuntsi, S., Koivula, M., Siitonen, J., 2018. Cross-taxon congruence and relationships to stand characteristics of vascular plants, bryophytes, polyporous fungi and beetles in mature managed boreal forests. Ecological Indicators 85, 137-145.

Kraus, D., Krumm, F., (eds.) 2013. Integrative approaches as an opportunity for the conservation of forest biodiversity. European Forest Institute. 284 pp.

Landres, P. B., Verner, J., Thomas, J. W., 1988. Ecological uses of vertebrate indicator species: a critique. Conserv. Biol. 2, 316-328.

Larrieu, L., Gonin, P., 2008. L'indice de Biodiversité Potentielle (IBP) : une méthode simple et rapide pour évaluer la biodiversité potentielle des peuplements forestiers. Rev. For. Fr. 6, 727-748.

Larrieu, L., Gosselin, F., Archaux, F., Chevalier, R., Corriol, G., Dauffy-Richard, E., Deconchat, M., Gosselin, M., Ladet, S., Savoie, J.M., Tillon, L., Bouget, C., 2018. Cost-efficiency of cross-taxon surrogates in temperate forests. Ecological Indicators 87, 56-65.

Larsson, T.B., 2001. Biodiversity evaluation tools for European forests. Ecol. Bull. 50.

Lindenmayer, D.B., Margules, C.R., Botkin, D.B., 2000. Indicators of biodiversity for ecologically sustainable forest management. Conserv. Biol. 14 (4): 941-950.

Lindenmayer, D. B., Franklin, J. F., Fischer, J., 2006. General management principles and a checklist of strategies to guide forest biodiversity conservation. Biological Conservation 131 (3): 433-445.

Lõhmus, A., Lõhmus, P., Vellak, K., 2007. Substratum diversity explains landscape-scale co-variation in the species-richness of bryophytes and lichens. Biological Conservation 135, 405-414.

Mandelik, Y., Roll, U., Fleischer, A., 2010. Cost-efficiency of biodiversity indicators for Mediterranean ecosystems and the effects of socio-economic factors. J. Appl. Ecol. 47 (6), 1179-1188. 
Mitchell, P.L., Kirby, K.J., 1989. Ecological effects of forestry practices in long-established woodland

742 and their implications for nature conservation, Occasional Paper 39, Oxford, Forestry Institute.

743 Moning, C., Müller, J., 2008. Environmental key factors and their thresholds for the avifauna of

744 temperate montane forests. Forest Ecology and Management 256, 1198-1208.

745 Moning, C., Müller, J., 2009. Critical forest age thresholds for the diversity of lichens, molluscs and

746 birds in beech (Fagus sylvatica L.) dominated forests. Ecological Indicators 9, 922-932.

747 Müller, J., Bütler, R., 2010. A review of habitat thresholds for dead wood: a baseline for management

748 recommendations in European forests. European Journal of Forest Research 129, 981-992.

749 Noss, R. F., 1990. Indicators for Monitoring Biodiversity. A Hierarchical Approach. Conservation

750 Biology 4 (4): 355-364.

751 Okland, B., Bakke, A., Hagvar, S., Kvamme, T., 1996. What factors influence the diversity of saproxylic

752 beetles? A multiscaled study from a spruce forest in southern Norway. Biodiversity and Conservation $7535(1): 75-100$.

754 Paillet, Y., Pernot, C., Boulanger, V., Debaive, N., Fuhr, M., Gilg, O., Gosselin, F., 2015. Quantifying the 755 recovery of old-growth attributes in forest reserves: A first reference for France. Forest Ecology and 756 Management, 346, 51-64.

757 Peres-Neto, P., Jackson, D., 2001. How well do multivariate data sets match? The advantages of a 758 Procrustean superimposition approach over the Mantel test. Oecologia 129, 169-178.

759 Pressey, R. L., 2004. Conservation planning and biodiversity: Assembling the best data for the job. 760 Conservation Biology 18 (6): 1677-1681.

761 Rameau, J.C., Mansion, D., Dumé, G., 1989. Flore Forestière Française. Tome 1: Plaines et collines. 762 IDF, Paris, $2464 \mathrm{p}$.

763 Rameau, J.C., Mansion, D., Dumé, G., 1999. Flore Forestière Française. Tome 2: Montagnes. IDF, 764 Paris, $2421 \mathrm{p}$.

765 Rose, F., 1993. Ancient British woodlands and their epiphytes, Br. Wildl. 5, 83-93.

766 Sabovljevic, M., Vujicic, M., Sabovljevic, A., 2010. Diversity of saproxylic bryophytes in old-growth and 767 managed beech forests in the central Balkans. Plant Biosystems 144 (1): 234-240. 
Schamberger, M., 1988. Monitoring wildlife habitat: a critique of approaches. Statistical Journal of the United Nations ECE 5: 303-313.

Schmidt, M., Kriebitzsch, W.U., Ewald, J., 2011. (Red.): Waldartenlisten der Farn- und Blütenpflanzen, Moose und Flechten Deutschlands. BfN-Skripten 299, 111 S. nähere Informationen, Waldartenlisten als EXCEL-Datei zum Download, Einzelbeiträge

Söderström, L., 1988a. The occurrence of epixylic bryophyte and lichen species in an old natural and a managed forest stand in northeast Sweden. Biological Conservation 45 (3): 169-178.

Söderström, L., 1988b. Sequence of bryophytes and lichens in relation to substrate variables of decaying coniferous wood in northern Sweden. Nordic Journal of Botany 8 (1): 89-97.

Sollander, E., 2000. European forest scorecards. WWF International, Gland, Switzerland.

Speight, M.C.D., Castella, E., Sarthou, J.P., Monteil, C., 2013. Speight. In: Speight, M.C.D., Castella, E., Sarthou, J.-P., Vanappelghem, C. (Eds.), Syrph the Net on CD, Issue 9. The Database of European Syrphidae. Syrph the Net Publications, Dublin.

Tews, J., Brose, U., Grimm, V., Tielborger, K., Wichmann, M.C., Schwager, M., Jeltsch, F., 2004. Animal species diversity driven by habitat heterogeneity/diversity: the importance of keystone structures. J. Biogeogr. 31 (1): 79-92.

Tölgyesi, C., Csaszar, P., Torma, A., Török, P., Batori, Z., Gallé, R., 2018. Think twice before using narrow buffers: Attenuating mowing-induced arthropod spillover at forest - grassland edges. Agriculture Ecosystems \& Environment 255: 37-44.

Tönnberg, M., 2001. Död ved i ekdominerade nyckelbiotoper - mängd, strukturer och betydelse för mossor och lavar. Examensarbete, Tillämpad Miljövetenskap. Göteborgs Universitet. Honours's thesis. [In Swedish; English summary], 39 pp.

Van Den Meersschaut, D., Vandekerkhove, K., 2000. Development of a stand-scale forest biodiversity index based on the state forest inventory. In: Hansen, Mark; Burk, Tom, eds. Integrated tools for natural resources inventories in the 21st century. Gen. Tech. Rep. NC-212. St. Paul, MN: U.S. Dept. of Agriculture, Forest Service, North Central Forest Experiment Station. 340-350. 
Venier, L., Mackey, B.G., 1997. A method for rapid, spatially explicit habitat assessment for forest

795 songbirds. J. Sustain. Forest 4, 99-118.

796 Vierikko, K., Pellikka, J., Hanski, I. K., Myllyviita, T., Niemela, J., Vehkamaki, S., Linden, H., 2010.

797 Indicators of sustainable forestry: The association between wildlife species and forest structure in

798 Finland. Ecological Indicators 10 (2): 361-369.

799 WCFSD 1999. Summary report: World Commission on Forests and Sustainable Development, World

800 Commission on Forests and Sustainable Development, Winipeg, Canada, 40 pp.

801 Brassel, P., Lischke, H. (eds) 2001: Swiss National Forest Inventory: Methods and Models of the

802 Second Assessment. Birmensdorf, SwissFederal Research Institute WSL. 336 pp.

803 Yoccoz, N. G., Nichols, J. D., Boulinier, T., 2001. Monitoring of biological diversity in space and time.

804 Trends in Ecology \& Evolution 16 (8): 446-453.

805 Zanella, A., Berg, B., Ponge, J.F., Kemmers, R.H., 2017. Humusica 1, article 2: Essential bases-

806 Functional considerations. Applied Soil Ecology 122: 22-41.

807 Zilliox, C., Gosselin, F., 2014. Tree species diversity and abundance as indicators of understory

808 diversity in French mountain forests: Variations of the relationship in geographical and ecological

809 space. Forest Ecology and Management 321, 105-116.

810 Zuur, A.F., leno, E.N., Elphick, C.S., 2010. A protocol for data exploration to avoid common statistical

811 problems. Methods Ecol. Evol. 1, 3-14. 